\title{
INTEGRATED NUTRIENT MANAGEMENT ON THE YIELD AND PROFITABILITY OF CAULIFLOWER
}

\author{
S. K. Bhowal ${ }^{1 *}$, M. H. Hossain ${ }^{2}$, M. M. Bashir ${ }^{3}$ \\ ${ }^{1}$ Scientific Officer, ${ }^{2}$ Principal Scientific Officer, ${ }^{3}$ Senior Scientific Officer, OFRD, BARI, Cumilla, Bangladesh \\ *Correspondng E-mail: shamal.bau@gmail.com
}

(Received: 27 September, 2020, Accepted: 27 October, 2020)

Keywords: Integrated nutrient management, Cauliflower, Yield, Profitability

\begin{abstract}
Field experiments were conducted at Multi Location Testing (MLT) sites of Chandina and Debidwer of Cumilla district, and Kasba of Brahmanbaria district under on-farm research division (OFRD), Bangladesh Agricultural Research Institute, Cumilla during 2016-18 to find out the appropriate dose of fertilizer for the maximum productivity of hybrid cauliflower varieties. Five integrated nutrient management packages such as $\mathrm{T}_{1}=$ Recommended fertilizer dose for high yield goal (HYG), viz. 40-20-38-7-0-0 NPKSZnB $\mathrm{Kg} \mathrm{ha}^{-1}, \mathrm{~T}_{2}=\mathrm{T}_{1}+1.5 \mathrm{tha}^{-1}$ vermicompost, $\mathrm{T}_{3}=\mathrm{T}_{1}+5 \mathrm{tha}^{-1}$ cowdung, $\mathrm{T}_{4}=\mathrm{STB}$ (107-61107-30-3.0-1.0 NPKSZnB Kg ha ${ }^{-1}$ and $\mathrm{T}_{5}=$ Farmers practices (114-74-123.5-0-0 NPKSZnB Kg ha ${ }^{-1}$ ) were used in the trial. The experiment was laid out in a Randomized Complete Block (RCB) design with six dispersed replications. The result revealed that the highest curd breadth $(21.68 \mathrm{~cm})$, individual curd weight $(1.86 \mathrm{Kg})$ and curd yield $(44.14 \mathrm{t}$ $\mathrm{ha}^{-1}$ ) was obtained from $\mathrm{T}_{2}$ treatment followed by $\mathrm{T}_{3}$ and $\mathrm{T}_{4}$ treatments. The lowest yield was found from farmers practice. Similarly the highest gross return (Tk. $626669.00 \mathrm{ha}^{-1}$ ) and gross margin (Tk. $493869.00 \mathrm{ha}^{-1}$ ) were also found from $\mathrm{T}_{2}$ treatment and the lowest (Tk. $457734.00 \mathrm{ha}^{-1}$ and $438066.00 \mathrm{ha}^{-1}$ ) respectively from farmer's practice $\mathrm{T}_{5}$.
\end{abstract}

\section{Introduction}

Cauliflower (Brassica oleracea var. botrytis L.) is the most popular cruciferous vegetable among the cole crops. The crop is the native of South Europe in the Mediterranean region and was introduced in India from England in 1822 (Chatterjee and Swarup, 1972). The edible part of cauliflower 'Curd' which is prefloral fleshy apical meristem. It is cultivated for its attractive curd which is used as raw cocked vegetables, curries, soups and pickles. It is predominant due to its attractive appearance, good taste, easy digestible, rich source of nutrients and high yielding capacity. It is a major source of protein, calcium, phosphorus, potassium, sodium, iron and vitamins.

Like other vegetable crops of the family, cauliflower is a heavy feeder of mineral elements, it removes large amount of macronutrients from the soil. Heavy manuring has been recommended for getting good yield of cauliflower by different workers in India (Roy, 1981, Randhawa and Khurana, 1983). Mineral nutrition plays an important role in influencing the quality of crops and it is fact that the soil health deteriorates due to continuous use of chemical fertilizers, (Savci, 2012). The integrated nutrient management paves the way to overcome these problems, which involves conjunctive use of chemical fertilizers and organic manures to sustain crop production as well as maintenance of soil health (Nanjappa et al., 2001). Systematic approach to nutrient management by tapping all possible sources of organic and inorganic in a judicious manner to maintain soil fertility and crop productivity is the essence of integrated nutrient management (INM) (Chowdhury et al., 2014). 
Farmers in Bangladesh produces cauliflower in the field ignoring the adequate and rational use of fertilizers. The inorganic fertilizer is much expensive for the common farmers and also hazardous to the soil environment. To combat the problems, it is necessary to adopt integrated nutrient management practices in Cauliflower production for boosting up the safe production. Considering the above facts, this experiment was initiated to find out an integrated fertilizer (inorganic and organic) dose for the maximum production of cauliflower.

\section{Materials and Methods}

The experiment was conducted at MLT sites Barura, Chandina and Brahmanbaria under On-Farm Research Division of Bangladesh Agricultural Research Institute, Cumilla during Rabi 2016-18 to find out the integrated fertilizer (inorganic and organic) dose for the cultivation of cauliflower. Five integrated nutrient management packages for cauliflower cultivation such as $T_{1}=$ Recommended fertilizer dose for HYG (40-20-38-7-0-0 NPKSZnB Kg ha ${ }^{-1}$ (FRG, 2012) $\mathrm{T}_{2}=\mathrm{T}_{1}+1.5 \mathrm{t} \mathrm{ha}^{-1}$ vermicompost, $\mathrm{T}_{3}=\mathrm{T}_{1}+5 \mathrm{t} \mathrm{ha}^{-1}$ cowdung, $\mathrm{T}_{4}=\mathrm{STB}$ (107-61-107-30-3.0-1.0 NPKSZnB Kg ha ${ }^{-1}$ and $\mathrm{T}_{5}=$ Farmers practices (114-74-123.5-0-0 NPKSZnB Kg ha ${ }^{-1}$ ) were used in the trial. The experiment was laid out in Randomized Complete Block (RCB) Design with six dispersed replications. Unit plot size was $(4.0 \mathrm{~m} \times 5.0 \mathrm{~m}) 20 \mathrm{~m}^{2}$ and the variety Hybrid Fulkupi Atlas 777 was used. Seedlings were transplanted at the main field maintaining row to row and plant to plant distance $60 \mathrm{~cm}$ and $40 \mathrm{~cm}$, respectively in last week of October to first week of November in both the years. Fertilizers were applied on the basis of experimental treatments. Dolochun was applied @ $1 \mathrm{t} \mathrm{ha}^{-1}$ in the whole experimental field. All intercultural and pest control measures were done as and when necessary. Harvesting of Cauliflower was done on 2nd to 3rd weeks of January. Initial soil properties of the farmer's field during 2017-18 are presented in Table 1. Data on yield and yield parameters of cauliflower were recorded and analyzed statistically at $5 \%$ level of probability using statistical program Statistix10 and presented in the Table 3. Cost of production was calculated on the basis of cost of land preparation, seed cost, fertilizer cost, pesticide cost, labor cost and land rent are presented in the Table 4.

\section{Chemical composition of manures used in the study}

Table 1 summarized the results of chemical analysis of the vermicompost and cowdung manure used in the study. Nutrients status of vermicompost was higher than cowdung. The soil quality includes soil reaction $(\mathrm{pH})$ and mineral nutrient elements has been presented in Table 2.

Table 1. Chemical composition of cowdung and vermicompost

\begin{tabular}{ccccccc}
\hline $\begin{array}{c}\text { Organic } \\
\text { manure }\end{array}$ & $\mathbf{p H}$ & $\begin{array}{c}\text { OM } \\
\mathbf{( \% )}\end{array}$ & $\begin{array}{c}\text { Total-N } \\
(\boldsymbol{\%})\end{array}$ & $\begin{array}{c}\text { Available P } \\
(\boldsymbol{\mu g} / \mathbf{g} \text { soil) }\end{array}$ & $\begin{array}{c}\text { Exchangeable K } \\
(\mathbf{m e q} / \mathbf{1 0 0 g})\end{array}$ & $\begin{array}{c}\text { Available S } \\
(\boldsymbol{\mu g} / \mathbf{g} \text { soil) }\end{array}$ \\
\hline Vermicompost & 7.3 & 18.30 & 0.72 & 251.31 & 0.73 & 409.81 \\
Cowdung & 8.2 & 12.27 & 0.56 & 196.64 & 0.65 & 81.10 \\
\hline
\end{tabular}


Table 2. Initial and post-harvested soil properties of the farmer's field

\begin{tabular}{|c|c|c|c|c|c|c|c|c|}
\hline $\begin{array}{c}\text { Soil } \\
\text { Properties }\end{array}$ & $\begin{array}{c}\text { Land } \\
\text { type }\end{array}$ & pH & $\begin{array}{c}\text { Organic } \\
\text { matter } \\
(\%)\end{array}$ & $\begin{array}{c}\mathrm{K} \\
{\text { Meq100 } \mathrm{ml}^{-1}}^{-1}\end{array}$ & $\begin{array}{c}\text { Total N } \\
(\%)\end{array}$ & $\mathbf{P}$ & $\begin{array}{c}\mathbf{S} \\
\mu \mathrm{gml}^{-1}\end{array}$ & B \\
\hline Initial & MHL & 5.2 & 2.40 & 0.12 & 0.12 & 5 & 2 & 0.28 \\
\hline \multicolumn{9}{|c|}{ Post-harvested soils } \\
\hline $\mathrm{T}_{1}$ & MHL & 4.48 & 2.89 & 33.88 & 0.17 & 7.21 & 61.06 & 0.27 \\
\hline $\mathrm{T}_{2}$ & MHL & 4.66 & 3.09 & 41.47 & 0.16 & 10.36 & 49.91 & 0.40 \\
\hline $\mathrm{T}_{3}$ & MHL & 4.51 & 3.17 & 41.00 & 0.16 & 9.24 & 36.56 & 0.36 \\
\hline $\mathrm{T}_{4}$ & MHL & 4.95 & 3.92 & 29.54 & 0.20 & 7.09 & 32.35 & 0.30 \\
\hline $\mathrm{T}_{5}$ & MHL & 4.59 & 2.45 & 22.1 & 0.17 & 8.21 & 19.11 & 0.32 \\
\hline Critical Level & - & - & - & 0.12 & 0.12 & 10 & 10 & 0.20 \\
\hline
\end{tabular}

Source: SRDI Regional Laboratory, Cumilla, Note: $\mathrm{T}_{1}=$ Recommended fertilizer dose for HYG $(\mathrm{FRG}-2012), \mathrm{T}_{2}=\mathrm{T}_{1}+1.5$ $\mathrm{t}$ ha $^{-1}$ vermicompost, $\mathrm{T}_{3}=\mathrm{T}_{1}+5 \mathrm{t} \mathrm{ha}^{-1}$ cowdung, $\mathrm{T}_{4}=\mathrm{STB}$ and $\mathrm{T}_{5}=$ Farmers practices

\section{Results and Discussion}

\section{Yield and yield attributing characters}

Yield components and curd yield of cauliflower under different integrated fertilizer management practices are presented in Table 3 . The result showed that there is no significant difference among $\mathrm{T}_{1}$, $\mathrm{T}_{2}$ and $\mathrm{T}_{3}$ treatments regarding the curd length. The shortest curd length $(22.23 \mathrm{~cm})$ was recorded in $\mathrm{T}_{4}$ treatment, which was statistically similar to farmers fertilizer management practice. The maximum curd breadth $(21.68 \mathrm{~cm})$ was found in $\mathrm{T}_{2}$ but it was statistically similar with $\mathrm{T}_{1}$ and $\mathrm{T}_{3}$. Individual curd weight of cauliflower differed significantly under different organic and inorganic fertilizer management practices. The maximum individual curd weight was recorded from $\mathrm{T}_{2}(1.86 \mathrm{~kg})$ that was followed by $\mathrm{T}_{3}$ and $\mathrm{T}_{4}$ treatments and minimum in $\mathrm{T}_{1}(1.47 \mathrm{~kg})$ i.e. $\mathrm{FRG} 2012$. There was no significant variation in plant population $\mathrm{m}^{-2}$, but numerically highest was in $\mathrm{T}_{3}$ and lowest in $\mathrm{T}_{5}$ treatment. The result reveled that among the different integrated nutrient management practices the maximum curd breadth $(21.68$ $\mathrm{cm})$ and individual curd weight $(1.86 \mathrm{~kg})$ was found in $\mathrm{T}_{2}$ that was statistically similar with $\mathrm{T}_{3}$ treatment (Table 3). Similar result was also reported by Sharma et al. (2019) who stated that integrated use of fertilizer, manure and bio fertilizer improves soil fertility and crop growth of Cole crops. So, the highest curd yield $\left(44.14 \mathrm{t} \mathrm{ha}^{-1}\right.$ ) was also obtained from $\mathrm{T}_{2}$ treatment and minimum curd yield was documented from farmer's practice. The variation in curd yield of cole crops were also observed by Kayesh et al. (2019) and Dey et al. (2018) who explains that it may be attributed to the total dry matter production and its partitioning to different yield contributing organs.

Table 3. Effect of different organic and inorganic fertilizer packages on yield and yield contributing characters of Cauliflower at Cumilla and Brahmanbaria (Av. 2016-18)

\begin{tabular}{cccccc}
\hline Treatments & $\begin{array}{c}\text { Curd length } \\
(\mathbf{c m})\end{array}$ & $\begin{array}{c}\text { Curd breadth } \\
(\mathbf{c m})\end{array}$ & $\begin{array}{c}\text { Individual curd } \\
\text { weight. }(\mathbf{K g} .)\end{array}$ & $\begin{array}{c}\text { Plant population } \\
(\mathbf{n o .})\end{array}$ & $\begin{array}{c}\text { Curd yield } \\
\left(\mathbf{t ~ h a} \mathbf{~ h}^{\mathbf{- 1}}\right)\end{array}$ \\
\hline $\mathrm{T}_{1}$ & 23.19 & 20.23 & 1.47 & 3.02 & 39.25 \\
$\mathrm{~T}_{2}$ & 24.59 & 21.68 & 1.86 & 3.15 & 44.14 \\
$\mathrm{~T}_{3}$ & 24.74 & 20.91 & 1.65 & 3.28 & 41.43 \\
$\mathrm{~T}_{4}$ & 22.23 & 19.18 & 1.58 & 3.13 & 41.04 \\
$\mathrm{~T}_{5}$ & 22.89 & 18.74 & 1.48 & 2.84 & 32.47 \\
\hline $\mathrm{CV}(\%)$ & 3.52 & 5.69 & 9.87 & 11.29 & 8.79 \\
$\mathrm{LSD}(0.05)$ & 1.56 & 2.16 & 0.30 & $\mathrm{NS}$ & 6.57 \\
\hline
\end{tabular}

Note: $T_{1}=$ Recommended fertilizer dose for HYG (FRG-2012), $T_{2}=T_{1}+1.5 t_{h} a^{-1}$ vermicompost, $T_{3}=T_{1}+5 t$ ha ${ }^{1}$ cowdung, $\mathrm{T}_{4}=\mathrm{STB}$ and $\mathrm{T}_{5}=$ Farmers practices 


\section{Cost and return analysis}

Cost and return analysis of different nutrient management packages of cauliflower has been presented in Table 4. From cost and return analysis it was revealed that the gross return, total cultivation cost and gross margin varies with different fertilizer management practices. Results showed that gross return (Tk. $626669.00 \mathrm{ha}^{-1}$ ) and gross margin (Tk. $493869.00 \mathrm{ha}^{-1}$ ) was highest in $\mathrm{T}_{2}$ treatment that received $1.5 \mathrm{t} \mathrm{ha}^{-1}$ vermicompost with recommended fertilizer dose for HYG (FRG, 2012) and the lowest in farmer's practice. The findings of Mahamud (2006) and Salwa (2019) agreed with that the combination of inorganic fertilizers with organic fertilizers would plays a vital role to ensure safe and economic food production.

Table 4. Economic analysis of Cauliflower as affected by different integrated nutrient management packages at Cumilla and Brahmanbaria (Average)

\begin{tabular}{|c|c|c|c|}
\hline Treatments & $\begin{array}{l}\text { Gross Return } \\
\left(\text { Tk. ha }{ }^{-1}\right)\end{array}$ & $\begin{array}{c}\text { Total Cost of Cultivation } \\
\left(\text { Tk. ha }{ }^{-1}\right)\end{array}$ & $\begin{array}{l}\text { Gross Margin } \\
(\text { Tk. ha }\end{array}$ \\
\hline $\mathrm{T}_{1}$ & 557018.00 & 140900.00 & 416118.00 \\
\hline $\mathrm{T}_{2}$ & 626669.00 & 132800.00 & 493869.00 \\
\hline $\mathrm{T}_{3}$ & 589299.00 & 158800.00 & 430499.00 \\
\hline $\mathrm{T}_{4}$ & 578966.00 & 140900.00 & 438066.00 \\
\hline $\mathrm{T}_{5}$ & 457734.00 & 120000.00 & 337734.00 \\
\hline
\end{tabular}

Price of input and output: Urea Tk. 16/kg, TSP Tk. 22/kg, MoP Tk. 15/kg, Gypsum Tk. $10 / \mathrm{kg}$, Cowdung Tk. 1/kg, Vermicompost Tk. $15 / \mathrm{kg}$ and

Cauliflower (Curd) Tk. 13/kg

\section{Chemical properties of soils of the experimental site}

The $\mathrm{pH}$ value of initial soil sample of the experiment was 5.2. Soils of the area are loams to clays in texture having very strongly acidic to slightly acidic in reaction (FRG, 2012). From the post-harvest soil analysis it was revealed that the $\mathrm{pH}$ values were lower than initial sample. It should be mentioned that the initial soil was collected in moist condition during the period of October. For this reason, $\mathrm{pH}$ value may be showed high than post-harvest soils. As well as post-harvest soils were collected in dry condition during the period of February, after harvesting of the crop. Organic matter (\%) of postharvest soils was higher than initial sample. Nutrients status of $\%$ total $\mathrm{N}$, available $\mathrm{P}$, exchangeable $\mathrm{K}$, available $S$ and $B$ of post-harvest soils were higher than initial soils sample (Table 2). This nutritional change occurred due to the addition of vermicompost and cowdung in the experimental plots. The changes of the chemical properties of initial and post-harvested soils was also mentioned by Ali et al. (2018) who stated that vermicompost in addition to inorganic fertilizers ensured favorable chemical properties of soil for the production of cauliflower.

\section{Farmers' Opinion}

Farmers' opined that they did not know the soil test based fertilizer application method and other integrated fertilizer management practices for Cauliflower production. They expressed that the higher yield of cauliflower could be possible by integration of organic and chemical fertilizers.

\section{Conclusion}

Based on the experimental results it was concluded that combination of organic and chemical fertilizer package viz., $1.5 \mathrm{t} \mathrm{ha}^{-1}$ vermicompost with recommended fertilizer dose for HYG had the maximum 
positive effect on plant growth, yield and yield contributing characters of cauliflower. Judicious application of organic manure in combination with chemical fertilizers is essential for yield maximization of cauliflower.

\section{References}

Ali, S., M.A. Kashem and M.M.H. Sarker. 2018. Effect of vermicompost on the growth and yield of cauliflower in acid soil of Bangladesh. J. Sylhet Agril. Univ. 5(1): 37 - 43.

Chaterjee, S.S. and V. Swarup. 1972. Indian cauliflower has as till greater future. Indian Hort. 10: 18-20.

Chowdhury, M.M.U., I.S.M. Farhad, S.K. Bhowal, S.K. Bhowmik and A.K. Choudhury. 2014. Fertilizer Management for Maximizing Soybean (Glycine max L.) Production in Char Lands of Bangladesh. The Agriculturists. 12(2): 98-102.

Dey, P., S. Srivastava, N.K. Lenka, K.C. Shinogi, A.K. Vishwakarma and A.K. Patra (Eds.). 2018. SAARC TRAINING Manual on Integrated Nutrient Management for Improving Soil Health and Crop Productivity, ICAR-Indian Institute of Soil Science, Bhopal, India.

FRG (Fertilizer Recommendation Guide). 2012. Bangladesh Agricultural Research Council (BARC), Farmgate, Dhaka.

Kayesh, E., M.S. Sharker, M.S. Roni and U. Sarker. 2019. Integrated nutrient management for growth, yield and profitability of Broccoli. Bangladesh J. Agril. Res. 44(1): 13-26.

Mahamud, M.S. 2006. Effect of different sources of nutrients on the growth and yield of Broccoli (cv. 'premium crop') and Cauliflower (cv. 'BARI 1'). MS Thesis, Faculty of Agriculture, Sher-eBangla Agricultural University, Dhaka.

Nanjappa, H.P., B.R. Ramchanrappa, and B.O. Mallikarjuna. 2001. Effect of integrated nutrient management on yield and nutrient balance in maize. Indian J. Agron. 46(4): 668-701.

Randhawa, K.S. and D.S. Khuraha. 1983. Effect of nitrogen, phosphorus and potassium fertilization on the yield and quality of cauliflower. Veg. Sci. 10(1): 1-7.

Roy, H. K. 1981. Effect of nitrogen on curd size and yield of cauliflower. Veg. Sci. 8(2): 75-78.

Salwa, M. and M.A. Kashem. 2019. Effect of nutrient management on growth and yield of Cauliflower hybrids in haor area. Bangladesh Agron. J. 22(1): 95-104.

Savci, S. 2012. An agricultural pollutant: chemical fertilizer. Intl. J. Environ. Sci. Dev. 3(1): 77-80.

Sharma, A., S. Singh and A. Saurabh. 2019. A review: Integrated nutrient management in cole crops. J. Pharmacog. Phytoche. SP4: 07-08. 